\title{
PESQUISAS SOBRE A FEBRE AMARELA (1881-1903): UMA REFLEXÃO VISANDO CONTRIBUIR PARA O ENSINO DE CIÊNCIAS
}

\section{Research on yellow fever (1881-1903): a reflexion aiming to contribute to Science Education}

\author{
Fernando Bastos ${ }^{l}$ \\ Myriam Krasilchik ${ }^{2}$
}

Resumo: $\mathrm{O}$ presente artigo focaliza episódios históricos relacionados à pesquisa médica acerca da febre amarela (1881-1903), buscando discutir (a) a influência que os fatores econômicos, sociais e políticos exercem sobre a pesquisa científica; (b) o caráter coletivo, controvertido e não-linear do processo de produção de conhecimentos na ciência; (c) a natureza arbitrária dos conhecimentos científicos, no sentido de que representam "formas de ver", e não são perenes ou elaborados apenas sobre bases racionais; (d) o papel pouco cabal desempenhado pelas demonstrações experimentais, que não se mostram "irrefutáveis"; e (e) o papel desempenhado pelos paradigmas, que conduzem não apenas a caminhos frutíferos, mas também a becos sem saída. O intuito é proporcionar subsídios que sejam úteis tanto aos pesquisadores como aos professores que atuam na área do Ensino de Ciências.

Unitermos: História da Ciência, Ensino de Ciências, febre amarela

Abstract: This paper focuses on historical episodes related to medical research concerning yellow fever (1881-1903), and attempts to discuss (a) the influence that economic, social and political factors exert on scientific research; (b) the collective, polemical and nonlinear nature of the process of production of knowledge in science; (c) the arbitrary characteristic of scientific knowledge, in that it represents "a certain point of view", and it"s not perennial or elaborated exclusively on objective grounds; (d) the limited role played by experimental demonstrations, that are not "irrefutable"; and finally (e) the role played by paradigms, that lead not only to fruitful ways, but also to dead-ends. The intention is to provide suggestionss that are useful both to the science education researchers and teachers.

Keywords: History of Science, Science Education, yellow fever

\section{Introdução}

O trabalho que apresentamos aqui é oriundo de uma investigação anterior que teve como objetivo elaborar um Guia de Estudos direcionado a professores e alunos do Ensino Médio, no qual a História da Ciência fosse empregada "como subsídio para a discussão de alguns importantes aspectos do processo de produção de conhecimentos na ciência” (Bastos, 1998a).

Naquela oportunidade constatamos que os episódios históricos relacionados à pesquisa médica sobre a febre amarela (1881-1903) constituíam excelentes exemplos ilustrativos para uma discussão acerca da ciência e dos cientistas, pois tais exemplos mostravam bem o caráter coletivo do processo de produção de conhecimentos, os aspectos subjetivos da ciência, o papel dos paradigmas, as relações existentes entre a atividade científica e o contexto econômico, social e político etc.

Além disso, os referidos exemplos permitiam uma reconstrução histórica que levasse em conta a contribuição dos cientistas brasileiros, o que julgávamos de grande interesse para a educação escolar, já que a ciência apresentada em nossas escolas é quase sempre européia.

\footnotetext{
${ }^{1}$ Professor Assistente Doutor, Departamento de Educação, Faculdade de Ciências, Unesp, Bauru (SP).

${ }^{2}$ Professora Titular, Departamento de Metodologia do Ensino e Educação Comparada, Faculdade de Educação, USP, São Paulo (SP).
} 
Assim, decidimos que o conteúdo do Guia de Estudos seria organizado em torno de relatos acerca da pesquisa médica sobre a febre amarela, e a partir de então passamos a empreender uma série de esforços de pesquisa bibliográfica e análise interpretativa relativos ao assunto.

Pois bem: nosso objetivo aqui é justamente apresentar ao leitor parte dos resultados que obtivemos ao longo desse percurso de pesquisa bibliográfica e elaboração de análises.

Não pretendemos discutir com detalhe, no presente texto, o possível uso pedagógico das reconstruçôes históricas e análises que estamos propondo. Entretanto, caso o leitor se interesse por essa questão, poderá consultar o relatório de pesquisa original (BASTOS, 1998a) ou um trabalho de investigação subseqüente no qual fizemos a avaliação de uma experiência pedagógica em que conteúdos e atividades constantes no Guia de Estudos foram desenvolvidos junto a uma turma de alunos do ensino médio (BASTOS, 1998b).

Finalmente, deve ser lembrado que os relatos e interpretaçōes apresentados aqui não são exaustivos e refletem um certo ponto de vista, bem como o acervo de material ao qual tivemos acesso, não excluindo outras possibilidades de reconstrução e análise.

\section{explicativas \\ A febre amarela nos séculos XVII a XIX: aspectos econômicos e hipóteses}

A partir de meados do século XIX a febre amarela tornou-se um flagelo permanente em vários pontos da América e da África.

Além disso, nas regiōes em que se instalara, a doença causou sérios prejuizos à atividade econômica.

No último quarto do século XIX, como resultado da substituição progressiva do capitalismo concorrencial pelo capitalismo monopolista, os países ricos (Estados Unidos, Inglaterra, França etc.) lançaram-se à conquista de novos mercados fora dos limites de suas próprias fronteiras (cf. HUBERMAN, 1986).

Assim, do ponto de vista dos países ricos, a febre amarela, que se havia estabelecido em largas áreas da América e da costa oeste da África, passou a representar não apenas um problema de saúde pública, mas também uma séria ameaça ao desenvolvimento econômico:

- A febre amarela vinha causando, nos Estados Unidos, perda de "vidas humanas" e "prejuízo econômico". Esse fato evidenciou-se principalmente após a epidemia de 1878 (cf. NOGUEIRA, 1955, p. 5).

- A febre amarela vinha constituindo importante obstáculo aos negócios que os países ricos mantinham em suas colônias e áreas de influência. Em regiōes onde a doença reinava, os trabalhadores braçais eram vitimados com frequiência e isso causava grandes transtornos às diferentes atividades em que os capitalistas europeus e americanos estavam investindo (produção de açúcar, bananas, petróleo etc.). Outro problema é que a doença dificultava a realização de obras de infra-estrutura (ferrovias, por exemplo) necessárias à expansão ou à própria sobrevivência dos empreendimentos em questão (cf. BREILH, 1991).

No Brasil, a febre amarela, além de produzir anualmente milhares de mortes, criava sérios problemas para os negócios de produção e exportação de café: vitimava trabalhadores rurais, afugentava a mão-de-obra imigrante e embaraçava as atividades portuárias no Rio de Janeiro e em Santos (cf. ANTUNES, 1992). 
As explicações mais antigas para a febre amarela e outras doenças "pestilenciais" da América estiveram vinculadas a observações que eram de domínio comum, ou seja, que não haviam sido produzidas mediante pesquisa sistemática. Tal situação perduraria até a década de 1880, quando Carlos Juan Finlay fez seus primeiros experimentos de inoculação da febre amarela por meio de mosquitos, e vários pesquisadores em diferentes países, influenciados pela teoria microbiana das doenças, começaram a procurar algum germe (bactéria ou fungo) que pudesse ser considerado como o agente causador da doença (cf. BENCHIMOL \& TEIXEIRA, 1993; O Brazil-Médico, 1897-1903).

A fim de proporcionar ao leitor um panorama geral acerca desses eventos, apresentamos na página seguinte o Quadro 1, que corresponde a uma linha do tempo referente a alguns importantes episódios relacionados à pesquisa da febre amarela durante o período de 1881 a 1903. Conforme o leitor poderá verificar, esse Quadro procura destacar os seguintes elementos, entre outros: hipóteses sobre a febre amarela; pesquisas experimentais e microbiológicas sobre a febre amarela; aspectos do contexto econômico no Brasil e no mundo; trabalhos dos médicos sanitaristas brasileiros.

No século XVII (e até o século XIX) a febre amarela seria atribuída ora à água suja e a alimentos estragados, ora a vícios e defeitos morais das populações vitimadas pela doença. Outra explicação repetidamente apresentada foi a de que a febre amarela estaria relacionada às condições climáticas que reinavam nos países tropicais.

No ano de 1647, em Barbados, não se sabia se a febre amarela "havia sido importada, ou se originara-se de comida estragada, do uso de água do pântano ou da intemperança dos colonos" (STERNBERG, 1890, p. 38).

Rocha Pitti, autor português citado por Sternberg (1890, p. 40-1), escreveu em 1730 que a doença pestilencial que grassou em Pernambuco no ano de 1686 (provavelmente a febre amarela) "deve ser atribuída aos pecados da população [...], corrompida pelos vícios para os quais foi atraída pela abundância e liberdade do Brasil". Ele afirma que "várias causas foram alegadas, sendo que a mais digna de atenção foi a chegada de alguns barris de carne que haviam voltado da ilha de São Tomé".

Stepan (1974, p. 63) lembra que no século XIX o clima tropical era considerado um dos principais fatores responsáveis "pelas doenças endêmicas e epidêmicas" no Brasil. E que a população do país, em razão da miscigenação, era considerada "sensual e passiva, suscetível às doenças e incapaz do controle e da racionalidade individual e coletiva para o progresso da civilização".

Em 1849, a epidemia de febre amarela em Salvador foi relacionada ao fato de o brigue norte-americano Brazil ter chegado ao porto carregando "pequenos barris de carne que havia apodrecido" (cf. STERNBERG, 1890, p. 41). 


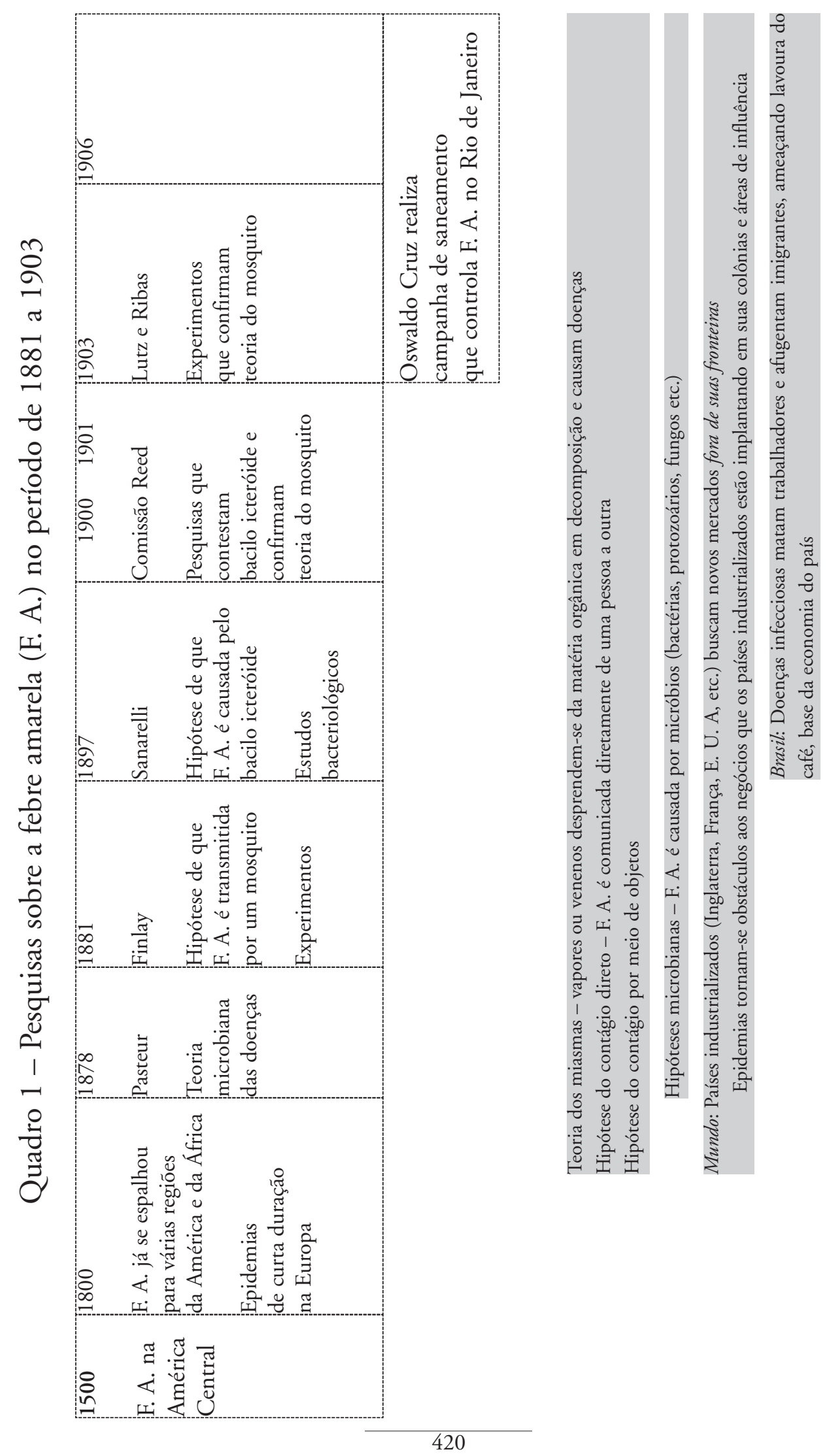


Pesquisas sobre a febre amarela...

Na década de 1880, temperatura, umidade, pressão atmosférica e eletricidade eram alguns dos fatores lembrados para explicar o aparecimento da febre amarela (cf. STERNBERG, 1890 , p. 36-7, 41).

Uma teoria antiga e importante que foi empregada para explicar a febre amarela foi a teoria dos miasmas.

No século XIX, muitos médicos em diferentes países acreditavam que a febre amarela era causada por "miasmas". Os "miasmas" eram eflúvios, vapores ou venenos que se desprendiam do solo, dos pântanos, do lixo ou dos esgotos e, depositando-se na atmosfera, produziam doenças. Originavam-se da matéria orgânica em decomposição. Supunha-se assim que as dejeções de pessoas doentes poderiam ser fontes de contágio, infectando casas e hospitais. Outro ponto às vezes enfatizado dizia respeito ao papel do clima. Acreditava-se que os "miasmas" eram gerados mais aceleradamente em locais quentes e que sua disseminação e conservação na atmosfera também era favorecida pelas altas temperaturas (cf. O Brazil-Médico, 1887-1897; ROSEN, 1994, p. 223-4).

A teoria dos miasmas teve origem na Grécia Antiga. Vigorou com maior ou menor intensidade até o início do século XX, talvez porque constituísse uma explicação plausível, abrangente e capaz de amoldar-se a novos fatos e evidências. Em face de sua longa história, apresentou inúmeras variantes, originárias da progressiva interação com outras teorias e explicaçóes, estando, por outro lado, profundamente arraigada no pensamento médico e no pensamento de senso comum, a tal ponto que não sucumbiu imediatamente à teoria microbiana das doenças. De fato, parece ter chegado a influenciar, no final do século XIX, até mesmo os próprios bacteriologistas, como se depreende do seguinte trecho extraído de Sternberg:

\section{[...] A cidade da Philadelphia [...] sofreu em 1793 uma devastadora epidemia [de febre amarela]. [...] "O dr. Rush e outros ressaltaram enfaticamente uma quantidade de café estragado que foi exposta no final de julho, num lugar (sobre o cais e numa doca vizinha) e sob circunstâncias que favoreceram a decomposição. Seu cheiro era altamente pútrido e repugnante, de tal modo que os habitantes [...], para evitá-lo, foram obrigados a fechar portas e janelas nos horários mais quentes $[\ldots]^{\prime \prime}$. \\ Parece provável que esse "café podre" era de fato o ninho no qual desenvolveu-se pela primeira vez o germe letal e exótico que originou essa epidemia fatal [...]. (STERNBERG, 1890, p. 45-6)}

Nos séculos XVIII e XIX também houve diferenças de opiniāo quanto ao fato de a febre amarela "ser contagiosa pelo contato direto ou não, ou pelo contato com as roupas infectadas" (STEPAN, 1976, p. 55).

Em 1853, na Venezuela, Louis Beauperthuy apontou pela primeira vez "o mosquito doméstico de pernas rajadas como espécie perigosa na propagação da febre amarela” (PESSÔA \& MARTINS, 1974, p. 874; ROSEN, 1994, p. 251). Essa hipótese, que foi retomada por Finlay em 1881, só começou a ser seriamente considerada a partir de 1899 ou 1900, de modo que acabou tendo pouca ou nenhuma importância nos debates sobre a febre amarela que foram travados no século XIX.

Note-se por fim que as divergências existentes entre os médicos da época em relação à febre amarela e outras doenças (cf. STERNBERG, 1890; O Brazil-Médico, 1897-1903; SALLES GUERRA, 1940; ROSEN, 1994) parece ter estado relacionada aos seguintes fatores, entre outros: (a) dissociação maior ou menor entre prática médica e investigação científica; (b) caráter altamente especulativo do pensamento médico, resultante, em parte, do divórcio mencionado em "a"; (c) formação precária dos médicos, principalmente em países pobres como o Brasil. Com efeito, durante a maior parte do século XIX, tanto no Brasil quanto nos 
Estados Unidos ou na Europa, a pesquisa médica "não fazia parte do trabalho do médico comum", ganhando maior ênfase somente de modo gradativo, com o surgimento de novas descobertas importantes e com o avanço dos programas de saneamento (STEPAN, 1976, p. 60).

\begin{abstract}
[...] O movimento de saúde pública na Europa e nos Estados Unidos foi acelerado pelas terriveis ondas de cólera que se espalharam de pais a pais a partir do inverno de 1831-1832; vagarosamente obteve-se uma compreensão de sua natureza contagiosa e das relaçôes entre as doenças epidêmicas e a sujeira e a pobreza. Juntas de saúde do governo foram estabelecidas para regulamentar a higiene pública das ruas e casas e impor quarentenas. O desenvolvimento da bacteriologia forneceu também uma compreensão da origem microbiana de muitas doenças. O papel do vetor inseto foi descoberto para a malária por volta de 1894. A soroterapia e a imunização foram acrescentadas ao arsenal das armas médicas contra as doenças [STEPAN, 1976, p. 60].
\end{abstract}

\title{
A etiologia da febre amarela por "micróbios": bactérias, fungos e protozoários
}

Os estudos pioneiros sobre a etiologia da febre amarela (décadas de 1880 e 1890) foram fortemente influenciados pela teoria microbiana das doenças.

Embora geralmente atribuída ao gênio individual de Louis Pasteur e Robert Koch, a teoria microbiana das doenças foi na verdade o ponto culminante do "esforço de muitos pesquisadores que, durante anos, procuraram descobrir os agentes causadores das moléstias infecto-contagiosas" (cf. CAMARGO, In: ANTUNES et al., 1992, p. 90). Uma brevíssima cronologia histórica já é o suficiente para mostrar que essa teoria não se estabeleceu senão com sucessivas contribuiçỗes de numerosos cientistas ${ }^{3}$ :

Antigüidade Observadores perspicazes lançam a hipótese de que certas doenças são causadas por "sementes", "animálculos" ou "vermes" e podem ser transmitidas por contágio.

1867 G. C. Bonomo descobre que as "vesículas de água" extraídas das pústulas de pessoas com sarna eram criaturas vivas muito diminutas.

1834 Agostino Bassi descobre que um fungo parasitário é agente causal da muscardina, moléstia do bicho-da-seda. Lança a hipótese de que doenças contagiosas como a varíola, o tifo exantemático, a peste, a sífilis e o cólera também se devem a parasitos vivos.

1835-1836 Giuseppe Balsamo-Crivelli e Audouin confirmam trabalho de Bassi sobre a muscardina.

1840 Jacob Henle apresenta fortes argumentos em favor da idéia de que os "venenos" causadores de doenças infecciosas são organismos vivos. Nota, entre outras coisas, que a matéria mórbida, após invadir o corpo, passa por um período de incubação e parece aumentar com o tempo (o que não ocorreria caso os agentes infecciossos fossem meras substâncias químicas sob a forma de "vapores" ou "miasmas").

1840 Henle propóe três etapas a serem cumpridas a fim de que se demonstre que um ser vivo específico é agente causador de uma doença: (a) demonstrar presença constante do parasito, (b) isolá-lo em meios externos e (c) reproduzir a doença a partir do parasito isolado.

\footnotetext{
${ }^{3}$ Cronologia organizada com base em Rosen (1994).
} 
1840-1860 Charles Cagniard-Latour e Theodor Schwann estudam o papel dos lêvedos na fermentação.

David Gruby demonstra a etiologia da tinha por um fungo do gênero Microsporum.

Pollender e Brauer estudam a relação do antraz com bastonetes encontrados no sangue de animais doentes.

1850-1870 Ferdinand Cohn estuda critérios para a classificação de bactérias segundo gêneros e espécies.

Joseph Schroeter, colaborador de Cohn, introduz os meios sólidos para cultivo de bactérias (batata, massa de farinha, carne, albumina de ovo).

1855 John Snow e William Budd concluem que o cólera é causado por um ser vivo específico e que a infecção se dá pelo consumo de água contaminada por fezes de pacientes.

1856 Pasteur descobre que a fermentação e a deterioração das misturas empregadas na fabricação de vinho, cerveja e álcool são causadas por microorganismos. Começa a supor que criaturas vivas diminutas podem ser agentes causais também de "doenças pútridas e contagiosas" (cf. ROSEN, 1994, p. 240).

1865 Joseph Lister estabelece técnicas de assepsia para o tratamento de traumatismos cirúrgicos e outros tipos de ferimentos.

Antoine Villemin consegue transmitir a tuberculose por inoculação, de animais doentes para animais saudáveis. Conclui que a causa da doença pode ser um germe microscópico capaz de se multiplicar no organismo.

1865-1866 Pasteur descobre que a pébrine e a flâcherie, doenças do bicho-daseda, são causadas por microorganismos específicos. ${ }^{4}$

1870-1880 Idéias "sobre microorganismos e doença estavam confusas". Vários investigadores "afirmavam ter visto, ou até mesmo demonstrado, ser possível uma espécie de organismo se converter em outra” (ROSEN, 1994, p. 241-2).

1876 Koch percorre pela primeira vez as etapas de verificação propostas por Henle e demonstra que o agente causador do antraz é um bacilo.

1878 Pasteur, Jubert e Chamberland apresentam à Academia de Ciências de Paris sua "sensacional comunicação" sobre "a teoria dos germes" (ANTUNES, 1992, p. 159).

1880 C. J. Eberth descobre o microrganismo causador da febre tifóide.

G. A. Hansen descobre o microrganismo causador da lepra.

Alphonse Laveran descobre o microrganismo causador da malária.

1882

1883

Koch descobre o microrganismo causador da tuberculose.

1894

Koch isola e cultiva o vibriāo do cólera.

A. Yersin e S. Kitasato descobrem o microorganismo causador da peste.

\footnotetext{
${ }^{4}$ Notar que há controvérsias a respeito desse episódio, conforme discutido por FERREIRA, R. F., MARTINS, R. A. Os estudos de Pasteur sobre os bichos-da-seda e a gênese da teoria microbiana das doenças. Perspicillum, v. 9, n. 1, p. 113$175,1995$. 
No final do século XIX, com o surgimento da teoria microbiana das doenças e o estabelecimento de um novo paradigma para as Ciências Biológicas (paradigma microbiológico), cientistas em todo o mundo voltaram seus esforços para a tarefa de isolar e identificar os "micróbios" (bactérias, fungos, protozoários) causadores das diferentes doenças conhecidas. Como se sabe hoje, porém, há doenças que não se devem nem a bactérias e nem a fungos ou protozoários. Assim, as investigaçôes de natureza microbiológica realizadas na época, embora tenham propiciado avanços importantíssimos, tais como a descoberta dos agentes etiológicos do cólera, da febre tifóide, da tuberculose, da malária e da peste, mais conseguiram confundir do que esclarecer determinadas questôes relacionadas à etiologia, ao modo de comunicação, à profilaxia e à terapêutica de doenças não "microbianas" (febre amarela, varíola, beribéri, escorbuto etc.). Isso evidencia um fenômeno muito interessante que tem acompanhado o processo de produção de conhecimentos na ciência e em outros setores da atividade humana: uma novo referencial ou paradigma (a perspectiva microbiológica, no caso) ilumina certas regiōes do terreno investigativo e ao mesmo tempo estimula o enveredamento por caminhos que levarão a "becos sem saída" (concluir, por exemplo, que a febre amarela é causada por uma bactéria ou fungo).

No caso das doenças cuja causa (ainda desconhecida) eram os vírus, havia boas razōes para se acreditar na existência de "micróbios" (bactérias ou fungos) que se instalavam no organismo dos pacientes. Por exemplo, conhecia-se perfeitamente a natureza contagiosa e epidêmica da varíola, do sarampo, da gripe e de outras doenças que hoje são classificadas como virais. Assim, os cientistas, animados pela teoria microbiana das doenças, examinavam amostras de sangue, tecidos e dejeçōes de pacientes com base no pressuposto de que os agentes etiológicos apareceriam sob a forma de bactérias, fungos ou protozoários. De fato, ainda não era totalmente clara a possibilidade de existência de organismos tão diminutos que seriam invisíveis ao microscópio óptico, muito embora F. Loeffler e P. Frosch, em 1898, houvessem demonstrado que a febre aftosa era produzida por "um vírus filtrável" (Rosen, 1994, p. 253).

Entre as doenças virais que foram estudadas como sendo "microbianas" estão a varíola e a febre amarela.

Em 1908 Stanislas von Prowazek e Henrique Aragão conseguiram "observar e descrever, com aumento de mil diâmetros, o micróbio [da varíola] [...], até então invisível para os bacteriologistas". Comprovou-se, mais tarde, "que a descoberta era falsa" (BENCHIMOL \& TEIXEIRA, 1993, p. 34).

A febre amarela, por sua vez, passou a ser sucessivamente atribuída, no final do século XIX, a diferentes "micróbios", principalmente bactérias e fungos, sendo que numerosos autores apresentaram os resultados de suas pesquisas e disputaram a primazia de uma suposta descoberta. De fato, cada observador se julgava "de posse do elemento específico da moléstia" (O Brazil-Médico, v. 4, n. 18, p. 147, 1890; cf. BIER, 1949, p. 597). Adolpho Lutz, referindo-se a esses episódios, observa o seguinte:

No periodo em que predominava a bacteriolologia, era natural que as pesquisas [sobre a febre amarela] fossem todas dirigidas para a descoberta de um germe novo. Eu mesmo gastei muito tempo e trabalho nesta ocupação. [...] os primeiros objetos de exame eram o vômito preto e as visceras mais alteradas, quer dizer o figado e os rins. O sangue também foi pesquisado em procura de espiroquetas e protozodirios [...]. (LUTZ, 1930, p. 133)

Em 1884, dr. Domingos Freire, professor da Faculdade de Medicina do Rio de Janeiro, anunciou ter isolado o germe da febre amarela, o Cryptococcus (Micrococcus) xanthogenicus, "micróbio" "da espécie das algas" cujos esporos contaminavam "as águas, o ar, a terra, os alimentos frios, os cemitérios e as enfermarias de hospital" (cf. BENCHIMOL, 1990, p. 20, 78). A fim de 
confirmar patogenicidade do Micrococcus, extraiu sangue de um cadáver de febre amarela e inoculou-o em um coelho; o coelho morreu e uma amostra de seu sangue foi injetada num porquinho da Índia; o porquinho da Índia também morreu e seu sangue foi aplicado num segundo animal da mesma espécie, o qual apresentou alteração de saúde temporária e posteriormente se restabeleceu. O Micrococcus estava abundantemente presente em todas as amostras de sangue empregadas durante o experimento. Os animais mortos foram "autopsiados". Segundo Freire, os dados clínicos e os resultados das "autópsias" comprovaram que em todos os casos a inoculação de Micrococcus resultou em desenvolvimento de um quadro típico de febre amarela. Argumentou-se, porém que as alterações de saúde descritas pelo dr. Freire, além de não corresponderem suficientemente àquelas que caracterizam a febre amarela (destaque-se por exemplo o fato de o coelho ter morrido em quinze minutos), poderiam ter sido provocadas antes pelas toxinas presentes no sangue do cadáver e não por uma ação patogênica do Micrococcus. De fato, mesmo que o Micrococcus tivesse sido letal para os animais, isso não significaria automaticamente que era ele o agente etiológico da febre amarela (cf. O Brazil-Médico, v. 1, n. 2, p. 49-50, 64-5, 90, 1887).

Segundo dr. Freire, o Micrococcus provinha de uma "granulação inicial" e depois era capaz de transformar-se sucessivamente em "vibriōes", "bactérias", "criptococos" e "micélios de leptothrix". Tal afirmação parece ter sido recebida com ceticismo, pois sugeria mistificação ou, na melhor das hipóteses, completo desconhecimento de princípios fundamentais da Biologia. Que processo seria esse em que espécies vivas diferenciadas se convertem umas nas outras? Caso se tratasse de um "cogumelo", o microorganismo em questão, de fato, poderia apresentar diferentes estágios evolutivos, mas ainda assim persistiria a suspeita sobre dr. Freire, inclusive por estar manifestando incapacidade em distinguir entre fungos e bactérias (cf. O Brazil-Médico, v. 1, n. 2, p. 145-6, 1887). Essas críticas todas, quer fossem justas ou não, não impediram dr. Freire de continuar divulgando sua hipótese bacteriana e, em 1887, apresentar seus trabalhos sobre o Cryptococcus xanthogenicus nos EUA e na França (cf. BENCHIMOL, 1990, p. 78).

Em razão do conjunto de sintomas que a caracterizavam, os quais incluíam dores abdominais, diarréias sanguinolentas e o conhecido "vômito negro", a febre amarela era freqüentemente entendida como uma moléstia gastro-intestinal (cf. MENDONÇA, 1903, p. 29). Segundo dr. Paul Gibier:

1. ${ }^{\circ}$ No sangue, urina, bile, serosidade do pericárdio e nas visceras (salvo no tubo digestivo) dos individuos mortos de febre amarela, não acha-se, na maioria dos casos, microorganismo algum.

Assim, é justo perguntar-se se, nos raros casos em que se encontra micróbios, não existirão eles acidentalmente nas culturas [...].

Entretanto, pode-se admitir como possivel a entrada fortuita na circulação, por causa de lesōes intestinais.

2. O intestino dos individuos vitimados pela febre amarela contém uma matéria negra escura, mais ou menos abundante e tóxica;

3. Da matéria negra tomada no intestino, eu isolei um bacilo que parece ter um papel importante na coloração desta substância, senão na patogenia da febre amarela. [...]. É um bacilo ora reto e curto, ora um pouco mais alongado e curvo. [...] A inoculação de uma pequena quantidade de seu líquido de cultura no intestino de animais (porcos da India, cães) provoca graves acidentes e mesmo a morte, com a formação, no intestino, de uma matéria análoga à que se observa no homem [...]

[...]

Cultiva-se bem n'água do mar e vive pelo menos seis meses, segundo muitas observaçôes [...]. [...] 
Se este bacilo é o que produz os acidentes do vômito negro, os caracteres que precedem dariam explicação do fato de não se observar a febre amarela endemicamente senão em certo número de portos de mar de paises quentes [...].

[...] se esta teoria [intestinal] está de acordo com os fatos, o tratamento que eu indiquei em uma conferência com os médicos de Havana (purgativos repetidos e desinfetantes intestinais) deverá facilmente achar explicação na moléstia que é destinado a combater [O Brazil-Médico, v. 2, n. 3, p. 263-4, 1888].

Algumas das explicações para febre amarela eram sui generis (cf. O Brazil-Médico, v. 6, n. 10 , p. 80,1892$)$ :

O impaludismo é produzido por uma mucedinea da importante família dos cogumelos, que, introduzida no estômago, acarretada pela água e alimentos, ai se desenvolve com espantosa rapidez, secretando uma substância tóxica [...].

Do estômago muitos são levados para o intestino delgado aumentando assim o campo de absorção e de proliferação, tornando gravissima a infecção, como acontece na febre tifóide.

[...]

Nos meses de grande calor há uma atonia do aparelho gastro-intestinal produzindo uma diminuição bastante sensivel do suco gástrico e entérico, manifestada pela falta de apetite e digestôes lentas. Nestas condições, [...] há a produção da fermentação que é um meio muito propicio para o desenvolvimento do parasita no estômago.

[...]

[...] nas febres perniciosa e amarela [grifo meu] o número de parasitas deve ser enorme e o seu crescimento rápido [...].

[...]

Em toda infecção palustre que tomamos para exemplo, e da qual a febre amarela não é mais que uma modalidade grave, isto é, cuja intoxicação é maior, o primeiro órgão que dá o grito de alarma é o estômago ou o intestino, que são os primeiros a sofrerem a ação tóxica e irritante do parasita, irritação que quando em maior grau produz vômito e diarréia.

[...]

Qual o meio de que devemos lançar mão para aniquilar o parasita? Conheço uma substância prodigiosa que em menos de 24 horas extermina a maior coorte de parasitas; é o iodo [...] [às colheres]. [...] depois se deverá administrar um purgativo, [...] a fim de eliminar os resíduos e as mucosidades que se acumulam no tubo gastro-intestinal [...].

Como se vê, "bolores", "mofos" e "cogumelos" vinham sendo apontados como agentes etiológicos da febre amarela. Note-se porém que em muitos casos a existência de fungos em amostras de tecidos, meios de cultura e outras preparaçôes poderia ter sido fruto de contaminação acidental (cf. MENDONÇA, 1903, p. 41).

A descoberta de organismos que se supunham ser os agentes etiológicos da febre amarela foi logo sucedida pela tentativa de produção de vacinas e outros líquidos profiláticos:

Nas sessôes de 21 de Março e de 4 de Abril de 1887, Domingos Freire, Paul Gibier e Rebourgeon ocuparam a atenção da Academia [de Ciências de Paris] com o micróbio da febre amarela e sua atenuação e mostraram que a mortalidade por esta moléstia caía de 10 por 100 nos não vacinados a 1 por 100 nos individuos vacinados.

Infelizmente, diz Gibier, as suas últimas pesquisas não confirmaram os resultados primitivamente obtidos [...] [O Brazil-Médico, v. 2, n. 3, p. 92, 1888]. 
Pesquisas sobre a febre amarela...

O dr. Gibier declarou

achar-se acorde com o professor Domingos Freire em considerar de natureza parasitária a febre amarela, reivindicando, todavia, para si a glória da descoberta do microorganismo patógeno, que diz ser um bacilo idêntico ao do cólera, e como tal diverso do assinalado pelo nosso laborioso conterrâneo [O Brazil-Médico, v. 2, n. 3, p. 265, 1888].

Com base em seus trabalhos sobre o Micrococcus xanthogenicus, dr. Domingos Freire passou a fabricar e aplicar uma vacina contra a febre amarela.

O processo de vacinação do dr. Freire foi contestado por várias razōes, entre elas a de estar sendo testado diretamente em seres humanos, sem que se conhecessem minimamente seus efeitos (cf. O Brazil-Médico, v. 3, p. 70, 1889). De fato, argumentou-se que as inoculações constituíam "um perigo para a população" ( $O$ Brazil-Médico, v. 3, n. 16, p. 124, 1889). Houve, no entanto, quem alertasse para a necessidade de que o sistema do dr. Freire fosse melhor estudado no sentido de se verificar sua possível eficácia (O Brazil-Médico, v. 3, n. 17, p. 129, 1889).

$\mathrm{O}$ dr. Alfredo Barcellos relatou ter experimentado em si mesmo "a inoculação do vírus xantogênico atenuado". Concluiu favoravelmente ao referido método, entendendo que o "líquido profilático" produz "os mesmos sintomas atenuados da febre amarela" (O Brazil-Médico, v. 3, n. 17, p. 130-2, 1889). Dr. Guilherme Xavier de Brito argumentou porém, que os sintomas produzidos pela vacina raramente se assemelham aos da febre amarela, desaparecendo "no fim de um ou mais dias, apesar dos vacinados não serem submetidos a tratamento algum”, o que significaria "que não foi inoculado nenhum organismo vivo, que continuasse multiplicando-se; senão simplesmente um produto tóxico [eliminável]” (O Brazil-Médico, v. 3, p. 71, 1889).

$\mathrm{O}$ dr. Freire, por sua vez, defendia-se alegando que suas inoculações preventivas contra a febre amarela (a) já haviam sido realizadas em larga escala durante três epidemias sucessivas, tendo produzido resultados positivos que não puderam ser contestados "pelos seus próprios antagonistas"; (b) haviam sido aprovadas e recomendadas "por médicos e associações médicas estrangeiras” (O Brazil-Médico, v. 3, n. 17, p. 132, 1889).

Em 1890, dr. George Miller Sternberg, empregando variados meios de cultura, principalmente "água de coco", procedeu a pesquisas "em larga escala no sangue obtido das cavidades do coração, no parênquima do fígado, baço, rins, no conteúdo do estômago e intestino e finalmente na urina obtida das paredes da bexiga”, com o intuito de localizar microorganismos que pudessem ser relacionados à febre amarela. Encontrou bacilos correspondentes aos que foram "verificados no conteúdo dos intestinos". Concluiu que um ou outro bacilo pudesse ser o elemento determinante da febre amarela, assegurando, porém, que no momento nada se poderia afiançar de positivo a respeito (O Brazil-Médico, v. 4, n. 18, p. 147, 1890).

Segundo dr. Sternberg, o "cryptococcus xanthogenicus do professor Domingos Freire", surpreendentemente, não foi encontrado em nenhum dos 30 cadáveres examinados. $\mathrm{O}$ bacilo de dr. Gibier, por sua vez, apareceu somente "em um terço das autópsias feitas", sem estar presente em abundância, de modo que não houve "razão plausível" para se supor que fosse ele "o agente infectuoso específico” (O Brazil-Médico, v. 4, n. 18, p. 148, 1890).

A hipótese microbiana mais famosa acerca da febre amarela foi a de Sanarelli.

Em 1897, Giovanni Sanarelli, médico italiano, diretor do Instituto de Higiene de Montevidéu, isolou, no sangue e nas vísceras de pacientes, um bacilo que ele afirmava ser o agente etiológico da febre amarela, o "bacilo icteróide" (MENDONÇA, 1903, p. 36; cf. BIER, 1949, p. 598; cf. BENCHIMOL, 1990, p. 20; cf. ANTUNES, 1992, p. 33). A descoberta causou grande impacto e suscitou numerosas pesquisas em diferentes países (cf. SALLES GUERRA, 1940, p. 71). De fato, a "teoria bacilar" proposta por Sanarelli era, na ocasião, uma 
explicação bastante plausível e atraente para a etiologia da febre amarela. Vejamos o que nos diz Adolpho Lutz:

\begin{abstract}
[...] Entre os numerosos trabalhos até hoje apresentados por autores que pretendiam ter resolvido o problema etiológico da febre amarela, a [...] publicação [de Sanarelli] era a única merecendo consideração séria por basear-se em métodos de investigação correspondentes ao estágio atual da ciência. A facilidade com que certos fatos por ele apresentados podiam ser verificados e a falta de argumentos positivamente contrários às deduçôes feitas, [...] tudo isso impunha a convicção de que o problema estava resolvido na sua questão fundamental. Esperava-se que os numerosos fatos mal concordantes que o autor ignorava ou não explicava satisfatoriamente chegariam com o tempo a ser conciliados com as teorias dele [LUTZ, 1903, p. 17].
\end{abstract}

Dando continuidade a suas pesquisas, dr. Sanarelli injetou em bois um líquido imunizante preparado com o "bacilo icteróide" e conseguiu assim obter um soro destinado ao tratamento de pacientes com febre amarela.

Em 1898, drs. Wasding e Geddings foram enviados a Cuba pelo General Wyman, cirurgião geral do Exército dos Estados Unidos, a fim de verificar a teoria bacilar de Sanarelli. Encontraram "o bacilo de Sanarelli em treze dos dezesseis dos pacientes estudados" (NOGUEIRA, 1955, p. 8).

Ainda em 1898, Arthur Mendonça, A. Lutz, G. Sanarelli e Vital Brazil extraíram "sangue venoso" de pacientes com febre amarela e aplicaram-no sobre o agar, conseguindo obter culturas puras do "bacilo icteróide". Mendonça e Emilio Ribas, então, inocularam as culturas em duas lebres e três cães, respectivamente, por meio de injeções subcutâneas e intravenosas. Todos os animais apresentaram alterações de saúde mais ou menos graves. Duas lebres e dois cães morreram. Amostras de material proveniente dos rins, do fígado e de outras vísceras dos animais mortos foram aplicados sobre o agar e originaram culturas puras do "bacilo icteróide". A partir dos dados clínicos e do resultado das "autópsias” e culturas, Mendonça concluiu que no cão o "bacilo icteróide" de fato produz "as lesões da febre amarela" (cf. MENDONÇA, 1903, p. 3-10). Durante o curso das experiências constatou-se também que o "serum A" e o "serum F" do dr. Sanarelli (extraídos de bois imunizados em Montevidéu) mostram grande "ação aglutinativa" quando adicionados às culturas do "bacilo icteróide" em caldo lactosado mas não exibem "ação curativa” notável quando empregadas em doentes de febre amarela. Segundo Mendonça, isso significava que "a terapêutica da febre amarela não encontra solução na serunterapia” (MENDONÇA, 1903, p. 10).

Nessa ocasião, Adolpho Lutz ficou convencido de que o "bacilo icteróide" era de fato "o micróbio específico da febre amarela", uma vez que havia sido encontrado apenas "na febre amarela" e apresentava "propriedades patogênicas [...] bem estabelecidas" (MENDONÇA, p. 15, 1903; cf. BENCHIMOL, 1990, p. 20).

Em 1899, no entanto, Sternberg já afirmava que o "bacilo icteróide" era um "saprófita patogênico ocasionalmente presente no sangue e tecidos de pacientes de febre amarela, mas sua relação etiológica ainda não foi estabelecida" (Journal of the American Medical Association, v. 33, n. 9, p. 537-8, 1899).

De fato, resultados obtidos por diversos pesquisadores mostravam que a frequiência com que se encontrava o "bacilo icteróide" nos tecidos e no sangue de pacientes mortos pela febre amarela era pequena. O próprio Lutz obteve resultados predominantemente negativos após examinar material proveniente de "60 cadáveres" e assinalou a possibilidade de que "a presença do bacilo de Sanarelli [nos pacientes] se deva simplesmente a uma infecção secundária" (cf. MENDONÇA, 1903, p. 12). 
Lutz estava inclinado a pensar que os diversos microorganismos que vinham sendo encontrados em pacientes de febre amarela não tinham qualquer importância especial:

[...] Confirmei que nem nos cortes, nem nos esfregaços se podia observar um germe que parecia em relação com as alteraçōes observadas. Quanto a culturas, quase sempre se obtinha germes variados e de aparência banal e verifiquei cedo que a invasão do sangue se pode dar já durante a vida [...]. Os germes invasores pertencem geralmente ao grupo dos coliformes [...], e devem vir em grande parte do intestino. O germe de Sanarelli também pertence a este grupo. Ao contrário de outros germes, foi obtido por uma técnica correta e por isso mereceu algum crédito. Mas sua presença era rara e o soro não dava resultado [...]. (LUTZ, 1930, p. 133-4).

Durante esse ano de 1899 as opiniōes de Lutz e Arthur Mendonça sobre a etiologia da febre amarela afastaram-se progressivamente. Mendonça mantinha-se fiel a "doutrina" de Sanarelli, enquanto Lutz rapidamente convenceu-se de que a "teoria bacilar" apresentava sérios problemas. Essa divergência acabou originando uma polêmica duradoura que chegou até mesmo a ganhar as páginas das imprensa diária. Hábil com as palavras, Mendonça construiu um discurso que, misturando argumentos válidos e "armadilhas de raciocínio", ainda hoje é capaz de causar forte impressão. Polemizou não apenas com Lutz mas também com vários outros médicos que contestavam a "doutrina" de Sanarelli ou que defendiam a teoria do mosquito (cf. MENDONÇA, 1903). Vejamos, a título de exemplo, trechos de um artigo em que Mendonça procura "desmontar" a argumentação de Lutz:

Para justificar a ineficácia do soro de Sanarelli, apelou o Sr. dr. Lutz para o fato de não ter ele poder bactericida nem antitóxico. S. S. não podia fazê-lo melhor; mas o que me surpreende, o que não posso compreender é como o soro de Yersin [contra a peste], de que S. S. é grande apologista, não tendo poder bactericida nem antitóxico tem, entretanto, poder curativo!!!!

A lógica, parece, atualmente não anda muito pelos arraiais da medicina.

[...] a bacteriologia [...] [diz que os soros] são excitadores da fagocitose!!! Expressão vaga, verdadeiro sofisma. O Sr. dr. Calmette chegou a ponto de declarar que após as injeçôes do soro os bacilos apresentaramse englobados pelos leucócitos na linfa do bubão pestoso.

Quem já fez esses exames sabe que esse fato não é verdadeiro, pois em doentes em que nunca se aplicaram tais injeçôes observa-se o fato do mesmo modo.

[...]

A propaganda feita pelo dr. Calmette traz o tom de uma imposição cientifica, e agora como o consumo parece não corresponder a essa propaganda, querem obrigar os comandantes de navio a ter sempre um bom estoque de soro para garantia dos passageiros. É assim que se continua a obra de Pasteur...

[...]

Em relação à etiologia da febre amarela, continua o $S r . d r$. Lutz, "não creio que esteja inteiramente fora de dúvida, muitos fatos bacteriológicos não estão de acordo com a teoria bacilar". Não sei quais sejam esses fatos epidemiológicos e por isso deixo de comentá-los. O sangue, diz ainda S. S., sempre estéril no primeiro periodo, dá raramente franca aglutinação [das culturas do bacilo em meio líquido] e o bacilo não pode isolar-se, pelos meios conhecidos, em mais da metade dos casos. Nada de estranho apresentam essas considerações de S. S. Na febre tifóide, que é da mesma natureza da febre amarela, não se encontra o germe no sangue no começo da moléstia e é regra também falhar nesse periodo a reação de aglutinação.

Quanto ao fato de não se isolar o bacilo de todos os casos, isso não fala contra o papel desse germe na febre amarela.

$O$ isolamento do bacilo de Eberth é tarefa banal e no entanto S. S. sabe que em diversas autópsias de casos de febre tifóide, perfeitamente caracterizados, não se pôde isolar o bacilo dessa moléstia 
pelos meios conhecidos. Seria mais razoável explicar esse fato, em relação à febre amarela, por não termos ainda um meio de cultura apropriado e tanto que diz S. S., "quando está presente só se obtém em raras colônias." [...].

É possivel que a presença do bacilo de Sanarelli, diz ainda o Sr. dr. Lutz, se deva simplesmente a uma infecção secundária que varia com freqüência segundo a estação e localidade em que se faz a observação.

Me parece ser esse um fato novo em bacteriologia, que a prática não sanciona [...].

[...] as observaçōes [...] feitas [no Brasil] concordam com as de Sanarelli, Sternberg e muitos outros, que encontraram o bacilo coli, estreptococos, estafilococos, piociànico etc. Apesar dos exames serem feitos em localidades e estaçôes diversas não foram notadas as diferenças citadas pelo Sr. dr. Lutz. Mais do que minhas palavras, fala o relatório do Sr. dr. Lutz, apresentado em $1 .^{\circ}$ de janeiro de 1899 ao dr. Diretor do serviço Sanitário.

Referindo-se à falta de poder aglutinativo e à impossibilidade de isolar o bacilo do sangue de muitos doentes, diz o Sr. dr. Lutz: "Entretanto, não fornecem razão suficiente para pôr em dúvida o papel etiológico deste organismo, até hoje só encontrado na febre amarela e cujas propriedades patogênicas são bem estabelecidas." (MENDONÇA, 1903, p. 15).

Mendonça afirmava ainda que as dificuldades "para o isolamento do bacilo icteróide" também se explicavam pela presença de diversos "micróbios de infecções secundárias" nos meios de cultura, assinalando porém, que essas dificuldades estavam a ponto de ser superadas, graças a uma nova técnica desenvolvida pelo dr. Ivo Bandi, que consistia em aplicar o soro específico sobre os meios de cultura, para aglutinar o bacilo e separá-lo de outros germes (cf. MENDONÇA, 1903, p. 38-9). Nas palavras de Mendonça:

\section{[...] aperfeiçoando a técnica de Sanarelli, o ilustre professor Ivo Bandi, que é incontestavelmente uma esperança da medicina de nossa terra e uma glória já da medicina italiana, conseguiu isolar esse bacilo de quase todos os casos de febre amarela e em detalhadas experiências, que constituem filigranas de bacteriologia, mostrou o valor patogênico desse microorganismo [MENDONÇA, 1903, p. 39].}

Em 1899, Walter Reed e James Carroll verificaram que "bacilo icteróide" apresentava "notável semelhança" ao bacilo do "hog-cholera nos aspectos referentes ao cultivo, à morfologia e à biologia". ${ }^{5}$ Concluíram assim, que o "micróbio" descoberto por Sanarelli constituía não mais que uma variedade do bacilo do hog-cholera, a qual deveria ser vista "como um invasor secundário na febre amarela". Verificaram também que o soro de um animal imunizado com o "bacilo icteróide" mostrava "forte reação aglutinativa" contra o bacilo do hog-cholera e viceversa (Journal of the American Medical Association, v. 33, n. 9, p. 672, 1899). Nessa ocasião, resultados similares foram obtidos por Adolpho Lutz e Vital Brazil no Instituto Bacteriológico de São Paulo (cf. MENDONÇA, 1903, p. 18).

Lutz assinalava ainda as seguintes evidências epidemiológicas contrárias à "teoria bacilar" de Sanarelli: (a) em localidades imunes, pessoas que têm contato com "doentes e cadáveres de febre amarela" não adoecem, apesar das "hemorragias abundantes contaminando tudo com um sangue suposto infeccioso"; se a febre amarela fosse moléstia causada por bactéria, seria de se esperar que material proveniente de doentes e cadáveres apresentasse poderosa ação infectante, tal como ocorria com a tuberculose e a peste; (b) a febre amarela é "dependente" de climas

\footnotetext{
${ }^{5}$ O Hog-cholera é o cólera suino, doença de porcos "causada por um vírus filtrável". A Salmonella choleraesuis "é um invasor secundário comum". A doença é caracterizada por "febre, diarréia, depauperação, manchas vermelhas difusas na pele, com inflamação e ulceração do intestino" (Osol, s. d.).
} 
e estaçôes quentes, "conquanto o bacilo suporte perfeitamente o frio e encontre no corpo humano a mesma temperatura em toda a parte"; moléstias dependentes "de temperaturas elevadas", como a malária, a filariose e a esquistossomose, não são "devidas a bactérios, mas a vermes e protozoários com hospedadores intermediários a sangue frio e, por isso, influenciados pela temperatura" (cf. MENDONÇA, 1903, p. 12, 17-18).

Em 1900, Reed, Carroll e Aristides Agramonte estudaram culturas preparadas com sangue de 18 pacientes vivos em vários estágios da febre amarela e com sangue e amostras de vísceras de 11 cadáveres. Os resultados de tal investigação sugeriram fortemente que o "bacilo icteróide" da Sanarelli não possuía "qualquer relação causal com a febre amarela, devendo, caso esteja presente, ser considerado, ao contrário, como um invasor secundário [do organismo do doente]" (cf. REED, CARROLL \& AGRAMONTE, 1901, p. 431).

Em pesquisas subseqüentes (1900-1901) Reed, Carroll e Agramonte demonstraram que a febre amarela era transmitida de pessoa a pessoa por meio da picada de mosquitos Culex fasciatus (ver detalhamento mais adiante). Eles também verificaram que o agente etiológico específico da febre amarela só se tornava transmissível depois de ficar incubado no mosquito por um período de 18 dias ou mais, e isso os levou a hipotetizar que esse agente era um protozoário, pois parecia plausível que um protozoário necessitasse de um determinado intervalo de tempo para completar o ciclo evolutivo que levaria à produção de suas formas infectantes. Criou-se, portanto, a seguinte situação: Reed e colaboradores haviam rechaçado o "bacilo icteróide", e em seu lugar propunham um protozoário. Ora, isso desagradou profundamente os adeptos de Sanarelli, que então passaram a atacar ferozmente a teoria do mosquito defendida pela Comissão Reed, para ver se conseguiam reerguer a sua teoria bacilar.

No Brasil, um adepto de Sanarelli que se tornou inimigo visceral da teoria do mosquito foi dr. Arthur Mendonça. Em 1902, ele assim polemizava com Lutz:

Quanto ao fato do soro do Hog-cholera aglutinar as culturas do bacilo icteróide, isso nada tem de extraordinário, pois que o soro tifico aglutina as culturas do germe da psitacose, moléstia bastante diferente da febre tifóide. Chega então o Sr. dr. Lutz, à conclusão que o germe da febre amarela não é um bacilo e que é veiculado pelo Culex teniatus.

S. S. sugestionado pelos trabalhos da comissão americana, que apresentou a hipótese de um protozoário, já dá o fato como provado e com leis extravagantes de patologia geral afirma que "as moléstias hoje conhecidas e que dependem de temperaturas elevadas não são devidas a bactérios, mas a vermes e protozoários.

Isso é pura fantasia [...]. (MENDONÇA, 1903, p. 25).

O cólera e a peste são moléstias da Asia, como a febre amarela é moléstia da América; está claro, pois, que as duas primeiras se mantêm na Ásia, devido às condiçôes de clima e no entanto são devidas a bactérios. O fato, pois de uma moléstia depender do clima não fala contra sua natureza bacteriana [...]. (MENDONÇA, 1903, p. 24).

Com o acúmulo de evidências favoráveis à hipótese de que o "bacilo icteróide" era um agente de infecção secundária e constituía apenas uma variedade do bacilo do hog-cholera, a "doutrina" de Sanarelli sofreu abalos consideráveis e foi progressivamente abandonada por vários cientistas em diferentes países, sem no entanto deixar de contar com adeptos fiéis e combativos. Para esse refluxo da "teoria bacilar" parecem ter sido decisivos os trabalhos de Reed, Carroll e Agramonte e também as numerosas pesquisas que demonstraram a inconstância com que o "bacilo icteróide" era encontrado nos tecidos de pacientes vivos e mortos. 
Apesar do acúmulo de evidências contrárias, as hipóteses bacterianas continuaram fazendo adeptos (cf. MENDONÇA, 1903, p. 34).

Referindo-se ao fato de que em 1903 as hipóteses bacterianas ainda persistiam insistentemente, sendo empregadas como argumento contra as medidas que Oswaldo Cruz estabelecera para o saneamento do Rio de Janeiro, E. Salles Guerra assim se pronuncia:

Os representantes da ciência oficial, repudiando a doutrina havanesa [teoria do mosquito], perfiIharam o bacilo icteróide de Sanarelli como patogênico; e para extingüir a febre amarela recomendavam desinfecçôes mais rigorosas, visto as executadas, nos últimos vinte anos, não terem dado resultado apreciável; e pontificavam, nesse sentido, quando Patrick Manson e outros próceres da bacteriologia já haviam verificado que o bacilo icteróide de Sanarelli, como o Criptococo xantogênico de Freire e o Tetragenus febris flava de Finlay, na ocasião, só tinham valor histórico, sendo que o pretendido bacilo de Sanarelli, que se encontrava nas autópsias de amarelentos, fora desclassificado, rebaixado, mais não era que o colibacilo da pneumo-enterite ou Hog-cólera do porco, fantasiado de icteróide. (SALLES GUERRA, 1940, p. 77).

\section{Pesquisas sobre o modo de comunicação da febre amarela}

Uma questão extremamente polêmica no final do século XIX foi o mecanismo pelo qual a febre amarela é comunicada ao homem.

Afirmava dr. Luiz Pereira Barreto em 1889:

Campinas não tem senão um pequeno bairro abastecido por água canalizada; quase toda a população só se serve de água de poços; e em fato de latrinas, não tem senão fossas térreas [...], e assestadas todas ao lado imediato dos poços.

Nestas condiçôes, compreende-se quais as conseqüências, que deviam ter inevitavelmente acarretado a contaminação do primeiro poço pelo agente mórbido [da febre amarela] [...]

De fato, uma das opiniões existentes era a de que o germe da febre amarela estava presente nas "dejeções humanas" e, por meio de "infiltrações no terreno", atingia os poços e envenenava a "água potável", de modo que as medidas de profilaxia indispensáveis incluiriam a obstrução dos poços e o abastecimento das cidades atingidas com "água potável impoluta” (cf. O BrazilMédico, v. 3, n. 15, p. 118-9, 1889; v. 4, n. 18, p. 147, 1890).

Em 1878, a terrível epidemia de febre amarela que eclodira nos EUA, além de cobrar "um pesado tributo em vidas humanas, causou ao país prejuízos econômicos [da ordem] de 100.000.000 de dólares".

Em razão dessa enorme destruição, o Congresso dos Estados Unidos aprovou uma lei em março de 1879, estabelecendo o Conselho Nacional de Saneamento, destinando-lhe a quantia de \$50.000,00. Essa quantia foi aumentada para \$500.000,00 em 2 de julho. A primeira resolução aprovada pelo Conselho foi organizar uma Comissão para visitar as Indias Ocidentais, com a tarefa de estudar o Vômito Negro [febre amarela] nas supostas áreas de origem da doença, com uma estadia de três meses em Havana, para em seguida realizar seu trabalho no Rio e em outras áreas endêmicas. Essa Comissāo, que eu chamo a PRIMEIRA COMISSÃO AMERICANA PARA O ESTUDO DA FEBRE AMARELA EM CUBA, foi formada pelos Drs. Stanford E. Chaille [...] [presidente], George Miller Sternberg, Secretário, Juan Guiteras, Engenheiro, Sr. Thomas Hardee e Messrs. Rudolph Matas e Henry Marcel [...]. (NOGUEIRA, 1955, p. 5).

Após três meses de estudo in situ, a comissão conclui que a febre amarela é uma doença epidêmica "transmissível", sendo que o agente capaz de transmiti-la "deve estar no ar" 
Pesquisas sobre a febre amarela...

(Nogueira, 1955, p. 5). De acordo com esse tipo de interpretação, portanto, os venenos ou partículas que invadiam o organismo durante o processo de infecção seriam oriundos de um indivíduo previamente infectado e não de um ambiente físico que exalava "miasmas".

Nessa ocasião, um dos cientistas que colaborava com os trabalhos da comissão americana era o médico cubano Carlos Juan Finlay.

Impressionado com a posição firmada pela comissão americana, dr. Finlay abandonou sua hipótese anterior - que relacionava o aparecimento da febre amarela à "alcalinidade da atmosfera" - e passou a defender a idéia de que a propagação da moléstia dependia basicamente de três condições:

- A existência de um caso anterior de febre amarela.

- A presença de um indivíduo capaz de adquirir a doença.

- A presença de um agente, independente tanto da doença como do paciente, mas necessário para a transmissão da mesma.

Em 14 de agosto de 1881, Finlay, após realizar experimentos bem sucedidos de inoculação em seres humanos, afirma estar convicto de que a febre amarela é transmitida por meio da picada de mosquitos Stegomyia fasciata (= Culex fasciatus = Aedes aegypti) infectados (Symposium on Yellow Fever, 1955, p. IV). Propõe assim a "formulação clássica" pela qual ficou conhecida a hipótese levantada 28 anos antes por Beauperthuy (Rosen, 1994, p. 252-3). Realiza durante os 20 anos seguintes numerosos experimentos em que participantes voluntários se deixam picar por mosquitos alimentados com sangue de amarelentos (Pessôa \& Martins, 1974, p. 874; Symposium on Yellow Fever, 1955, p. IV). Obtém, no entanto, resultados duvidosos.

Em razão da extravagância da hipótese que defendia e do caráter pouco conclusivo dos resultados experimentais que obtivera, Finlay não conseguiu reunir seguidores para a sua "doutrina" e chegou a ser tratado com desprezo ou ridículo (Symposium on Yellow Fever, 1955, p. IV, 9).

Mais tarde tornou-se evidente que as experiências de Finlay não poderiam mesmo ser "demonstrativas [...] nas condições em que eram feitas":

\section{[...] É pefeitamente natural que [Finlay] não se lembrasse do desaparecimento do vírus da circu- lação no segundo período da moléstia, nem da necessidade de uma incubação tão prolongada no mosquito [...]. No fim do século passado, com os novos conhecimentos a respeito da filariose e da malária, a transmissão pelo mosquito já não parecia uma utopia [...]. Assim mesmo, os america- nos somente se lembraram da teoria de Finlay, depois que, como tantos outros, não obtiveram resul- tado com o exame bacteriológico [...]. (LUTZ, 1930, p. 133).}

Enquanto Finlay, desacreditado, continuava sustentando a teoria do mosquito e realizando experimentos de inoculação, duas outras comissões norte-americanas para o estudo da febre amarela foram enviadas a Cuba, a primeira em 1888, e a segunda em 1898, ambas obtendo resultados pouco expressivos (NOGUEIRA, 1955, p. 7-8).

Em 1900, George Sternberg designou Walter Reed, Aristides Agramonte, Jesse W. Lazear e James Carroll para compor uma nova comissão encarregada de conduzir pesquisas sobre a febre amarela em Cuba (cf. ROSEN, 1994; cf. NOGUEIRA, 1955, p. 10). Nessa oportunidade, Sternberg, impressionado com as descobertas recentes sobre a malária (1898), recomendou ao dr. Reed que desse "especial atenção à possibilidade de transmissão [da febre amarela] por alguns insetos", acrescentando porém que "os experimentos do dr. Finlay parecem mostrar que o inseto não era um mosquito do gênero Culex" (cf. NOGUEIRA, 1955, p. 10; 
cf. GALVÃO et al., 1992, p. 138). Note-se que um dos fatores determinantes para essa decisão de testar a hipótese do mosquito foram os sucessivos fracassos em investigações que partiam do pressuposto de que o agente etiológico da febre amarela fosse uma bactéria (cf. LUTZ, 1930, p. 133; cf. NOGUEIRA, 1955, p. 11). De fato, tanto Sternberg como Reed e Carroll já haviam eles mesmos conduzido pesquisas anteriores que sugeriam haver pouca ou nenhuma relação entre febre amarela e bactérias (ver citações anteriores).

A comissão iniciou seus trabalhos estudando culturas preparadas com sangue de 18 pacientes vivos em vários estágios da doença e com sangue e amostras de órgãos de 11 cadáveres. Os resultados de tal investigação, conforme já mencionado, sugeriram fortemente que o "bacilo icteróide" de Sanarelli não possuía "qualquer relação causal com a febre amarela". $\mathrm{Na}$ mesma ocasião, "onze indivíduos não-imunes" foram inoculados por meio da picada de mosquitos Culex fasciatus "que se haviam alimentado com sangue de amarelentos". Dois desses indivíduos adoeceram, e a comissão concluiu que o mosquito realmente serve "como um hospedeiro intermediário para o parasita da febre amarela” (cf. REED, CARROLL \& AGRAMONTE, 1901, p. 431).

Entre novembro de 1900 e janeiro de 1901, Reed e colaboradores conduziram experimentos em que procuraram verificar simultaneamente a teoria do mosquito, a transmissão da febre amarela por meio de fomites e vários outros pontos relacionados ao processo de invasão do organismo humano pelo germe da febre amarela:

(a) - Mosquitos Culex fasciatus foram alimentados em doentes de febre amarela que se encontravam em diferentes estágios da moléstia (1을 $2^{\circ}, 3^{\circ}$ e $5^{\circ}$ dias). - Após um intervalo que variou entre 3 e 27 dias, os mosquitos foram aplicados em sete pessoas que nunca haviam tido febre amarela antes (três cidadãos americanos e quatro imigrantes espanhóis).

- Em cada sessão de aplicação de mosquitos uma determinada pessoa era picada por cerca de três insetos. Aguardava-se então três ou quatro dias; se a pessoa manifestasse a doença, o experimento era dado por encerrado; se a pessoa continuasse saudável, uma nova sessão de aplicação de mosquitos era realizada. Cada pessoa foi exposta aos mosquitos até no máximo quatro vezes.

- 12 pessoas foram mantidas no local dos experimentos sem ter contato com os mosquitos.

- Das sete pessoas que foram picadas pelos mosquitos infeccionados (100\%), seis adoeceram (86\%) e uma permaneceu saudável (14\%).

- As seis pessoas mencionadas acima só adoeceram depois que foram picadas por mosquitos que haviam sido infeccionados a 17 dias ou mais.

- As 12 pessoas que permaneceram no local dos experimentos sem ter contato com os mosquitos não adoeceram (cf. REED, CARROLL \& AGRAMONTE, 1901, p. 432-5, 439).

(b) - Quatro indivíduos receberam "injeção subcutânea” de sangue retirado de pacientes com febre amarela; três deles (75\%) desenvolveram a doença;

- Culturas foram feitas com o mesmo sangue injetado nos voluntários e em nenhuma delas apareceu o "bacilo de Sanarelli" (cf. REED, CARROLL \& AGRAMONTE, 1901, p. 436); 
(c) - Sete voluntários passaram 20 noites consecutivas em contato com vestimentas e roupas de cama sujas de vômito, fezes e sangue de pessoas doentes; esses voluntários ficaram alojados numa pequena casa em que o ar era quente, úmido e não circulava direito; nenhum deles apresentou qualquer alteração de saúde (cf. REED, CARROLL \& AGRAMONTE, 1901, p. 437-8).

A fim de que não se alegasse que os indivíduos inoculados haviam adoecido em conseqüência do contato com "miasmas", os experimentos foram realizados numa área "bem drenada, livremente exposta à luz do sol e ao vento" (cf. REED, CARROLL \& AGRAMONTE, 1901 , p. 432). Note-se ainda que o uso de seres humanos nesses experimentos esteve relacionado ao fato de que a doença aparentemente não se desenvolvia em animais de laboratório (ratos, coelhos, cobaias, cães etc.) (ROSEN, 1994, p. 253).

Com base nos resultados obtidos, Reed e colaboradores chegaram às seguintes conclusōes:

1. O mosquito $C$. fasciatus serve como hospedeiro intermediário para o parasita da febre amarela.

2. A febre amarela é transmitida ao indivíduo não-imune por meio da picada do mosquito que se alimentou previamente com sangue de pessoas doentes.

3. [...] [Nos meses mais quentes de ano, um] intervalo de cerca de doze dias parece ser necessário antes que o mosquito seja capaz de comunicar a infecção.

$[\ldots]$

5. A febre amarela também pode ser experimentalmente produzida por meio da injeção subcutânea de sangue colhido [...] durante o primeiro e segundo dias da doença. $[\ldots]$

8. A febre amarela não é comunicada por fomites, portanto é desnecessária a desinfecção de vestimentas, roupas de cama e outros objetos supostamente contaminados pelo contato com indivíduos doentes.

9. Uma casa poderá ser considerada infectada com a febre amarela somente quando houver em seu interior mosquitos contaminados capazes de comunicar o parasita da doença.

10. A disseminação da febre amarela poderá ser mais efetivamente controlada com medidas objetivando a destruição dos mosquitos e a proteção dos doentes contra a picada desses insetos.

11. Embora o modo de propagação da febre amarela já tenha sido definitivamente estabelecido, a causa específica dessa doença ainda está para ser descoberta. (REED, CARROLL \& AGRAMONTE, 1901, p. 439-40).

Reed e colaboradores assinalaram também que o intervalo necessário "antes que o mosquito seja capaz de comunicar infecção" pode ser de dezoito dias ou mais nos meses frios e representa "o tempo requerido para que o parasita passe do estômago do inseto para suas glândulas salivares” (REED, CARROLL \& AGRAMONTE, 1901, p. 436). Conforme mencionado anteriormente, a existência desse período de incubação no mosquito serviu de argumento para que a comissão Reed propusesse que o agente etiológico da febre amarela era um protozoário.

Os experimentos da comissão Reed conseguiram convencer vários pesquisadores em diferentes países, mas mesmo assim, sofreram contestação, principalmente por parte dos "seguidores de Sanarelli" (Journal of the Americam Medical Association, v. 36, n. 11, p. 704, 1901). Como a febre amarela, "durante o período de realização da pesquisa", estava grassando em Havana e 
também em Quemados, cidade localizada nos arredores da área escolhida para os experimentos (cf. REED, CARROLL \& AGRAMONTE, 1901, p. 438), argumentou-se que os indivíduos inoculados poderiam ter contraído a doença não pela picada dos mosquitos, mas pela exposição aos "miasmas" que impregnavam a atmosfera da região. Assim, para muitos cientistas, não ficou descartada a hipótese da existência "de outros meios para a transmissão da moléstia, além do mosquito" (cf. ANTUNES, 1992, p. 33). O Instituto Pasteur de Paris chegou inclusive a formar uma comissão médica para checar independentemente a teoria do mosquito (cf. NEIVA, 1940, p. 60).

Os trabalhos de Reed e colaboradores em Cuba foram o estopim de um intenso debate que se travou entre adeptos da teoria bacilar de Sanarelli e adeptos da teoria do mosquito. A comissão Reed, além de ter rechaçado o "bacilo icteróide" e proposto em seu lugar um protozoário, havia demonstrado que vestimentas e roupas de cama sujas de sangue, vômito e fezes de amarelentos não produziam contágio, o que parecia ir contra a idéia de que os dejetos dos doentes pudessem estar contaminados com bacilos. A resposta dos seguidores de Sanarelli a esses argumentos foi basicamente a de atacar a teoria do mosquito por todos os lados, para ver se salvam o "bacilo icteróide".

A afirmação de que os trabalhos da comissão Reed haviam produzido resultados conclusivos despertava profundo inconformismo em médicos como dr. Arthur Mendonça:

\section{[...] todos os que se têm ocupado com os fatos de Cuba só se lembram da guerra ao mosquito, impressionando-se com uma das arestas do problema em vez de encará-lo em seu conjunto. Ninguém, ao que consta, fez experiências sistemáticas com o mosquito na febre tifóide e outras moléstias bacterianas e, enquanto isso não se fizer, ninguém tem o direito de afirmar que a trans- missão pelo mosquito não se coaduna com a doutrina bacteriana.}

Diante dessa confusäo, desse caos, eu continuo a sustentar que o germe etiológico da febre amarela é o bacilo icteróide, descoberto por Sanarelli, cuja pesquisa [...] está muito simplificada e ao alcance de qualquer bacteriologista. (MENDONÇA, 1903, p. 44).

Apesar das numerosas controvérsias que se vinham estabelecendo, o Exército Americano considerou que os trabalhos da Comissão Reed sugeriam caminhos seguros para o controle da febre amarela. Assim, entre fevereiro e setembro de 1901, o General William C. Gorgas, determinando o combate ao Culex fasciatus e outras medidas afins, organizou ações de saneamento que conseguiram extingüir completamente a febre amarela em Havana (cf. MENDONÇA, 1903, p. 69). Os excelentes resultados obtidos nessa oportunidade transformaramse em evidências adicionais em favor da teoria do mosquito (ROSEN, 1994, p. 253; NOGUEIRA, 1955, p. 13).

Para os adversários da teoria do mosquito, no entanto, a extinção da febre amarela em Havana deveria ser atribuída antes a "obras sanitárias" e "medidas de desinfecção" que vinham sendo realizadas na cidade e não especificamente à destruição do Culex fasciatus (RIBAS, 1909, p. 200; MENDONÇA, 1903, p. 56-7). Nas palavras de Arthur Mendonça:

[...] consigna dr. Gorgas que "o exército americano tomou a seu cargo a repartição sanitária de Havana em 1898, quando o número de óbitos atingia a 21.252 por ano, e a entrega com 5.720 óbitos em 1901!"

Não será venturoso presumir, pois, que [...] [às] grandes obras de saneamento em Havana [...] se deva também a extinção da febre amarela, analogamente ao que aconteceu em Nova-Orleans, em São Paulo e em Campinas onde ninguém cogitou a transmissibilidade pelo stegomyia. 
Pesquisas sobre a febre amarela...

\begin{abstract}
Todos sabem que em Santos e Campinas, para só citar os focos importantes deste Estado, a extinção da febre amarela foi obtida com o rigoroso policiamento sanitário, sem a morte de um só mosquito. Muito antes de Cuba, o Estado tinha varrido a febre amarela de seus dois focos principais sem se preocupar com esse inseto. (MENDONÇA, 1903, p. 57)
\end{abstract}

Para Mendonça, além disso, a Comissão Reed, ao afirmar que o germe da febre amarela não era "um bactério e sim um protozoário", baseava-se apenas analogias duvidosas com a malária, não dispondo de qualquer fato concreto para fundamentar suas conclusões (cf. MENDONÇA, 1903, p. 30).

Mendonça argumentou ainda que o mosquito poderia ser, na melhor das hipóteses, apenas um "meio mecânico" de transmissão da febre amarela, ficando ainda "por provar", nesse caso, "que ele é o único veículo dessa moléstia” (MENDONÇA, 1903, p. 43).

Durante o ano de 1901, Emilio Ribas, que então ocupava o cargo de diretor do Serviço Sanitário do Estado de São Paulo ${ }^{6}$, acompanhou atentamente os trabalhos da Comissão Reed em Cuba, "não só pelos detalhados relatórios recebidos", mas também por cartas e telegramas que lhe foram dirigidos "pelos Drs. Carlos Finlay e James Carroll” (RIBAS, 1917, p. 123). Impressionado com os resultados obtidos, que explicavam muitos dos fatos que vinham sendo observados no estado de São Paulo, deflagrou imediatamente "uma intensa campanha contra o Stegomyia fasciata, apresentando a medida como a única profilaxia eficaz contra a expansão da epidemia” (cf. BRAZIL, 1936, p. 9; cf. ANTUNES et al., 1992, p. 67-68).

Para a maior parte dos médicos brasileiros, no entanto, a transmissão da febre amarela por um mosquito era uma hipótese fantasiosa e até mesmo ridícula. Muitos argumentavam que os experimentos da comissão Reed em Cuba tinham sido uma farsa, ou que os participantes daqueles experimentos tinham adoecido não por causa das picadas dos mosquitos, mas por causa de água contaminada, de "miasmas" que estavam no ar etc. O mesmo tipo de opinião encontrava-se amplamente disseminado na imprensa e entre os membros da classe política. Assim, nesse momento, a campanha contra o mosquito e o próprio Ribas tornam-se alvo de violentas críticas (cf. BRAZIL, 1936, p. 10).

Diante da forte oposição que se formou contra a idéia do combate ao mosquito, Emilio Ribas e Adolpho Lutz decidiram repetir em São Paulo a experiência cubana sobre o modo de comunicação da febre amarela, a fim de colher provas que possibilitassem derrubar os argumentos de seus adversários (cf. ANTUNES et al., 1992, p. 67-68).

Quase um ano se passou antes que os experimentos de Ribas e Lutz pudessem ser realizados. Tal demora deveu-se ao fato de que "o maior número de casos que serviam para se alimentar os mosquitos, tiveram um desfecho fatal; em outras tentativas os mosquitos, infectados em lugares muitos distantes, morriam antes do tempo". De fato, Ribas e Lutz não queriam prosseguir com sua demonstração enquanto não pudessem excluir "o vírus mais violento". A intenção era evitar que os experimentos produzissem "infecções fatais" (LUTZ, 1930, p. 131).

As condições ideais para a realização da experiência paulista sobre o modo de comunicação da febre amarela foram conseguidas em 1902. Larvas de mosquitos foram coletadas em Itu e criadas no Instituto Bacteriológico até a fase adulta (cf. RIBAS, 1909, p. 200; cf. DIRECTORIA..., 1936, p. 125; cf. BRAZIL, 1936, p. 10).

Os mosquitos adultos foram remetidos a São Simão e ali se alimentaram em quatro pacientes de febre amarela (Benjamin Rosanini, Joaquim Tarquinio, Nicola Rassoti e Alexandrina), entre novembro de 1902 e janeiro de 1903 (DIRECTORIA..., 1936, p. 130-2).

Os experimentos realizaram-se no Hospital de Isolamento de São Paulo e foram acompanhados por uma comissão médica formada pelos doutores Luiz Pereira Barreto, Antonio

\footnotetext{
${ }^{6}$ O Serviço Sanitário era órgão do governo estadual responsável pelo combate às doenças infecciosas 
Gomes da Silva Rodrigues e Adriano Julio de Barros, tendo sido presenciados também pelos doutores Candido Espinheira (diretor do Hospital de Isolamento), Victor Godinho (médico interno do Hospital de Isolamento) e Carlos Meyer (ajudante do Instituto Bacteriológico).

Em 15 de dezembro de 1902 Ribas e Lutz iniciaram sua "1. a série de experiências". Juntamente com os voluntários Domingos Pereira Vaz (paranaense) e Oscar Marques Moreira (carioca residente em Santos), deixaram-se picar pelos insetos infeccionados em São Simão. Note-se que Ribas, Lutz e Moreira haviam permanecido em "focos intensos da doença", podendo eventualmente ter adquirido imunidade natural, enquanto Vaz havia residido apenas "em localidades imunes", devendo ser, portanto, suscetível à moléstia (RIBAS, 1909, p. 200; RIBAS, 1917, p. 125; LUTZ, 1930, p. 128-9).

Em 18 de dezembro de 1902, como não apresentaram qualquer "alteração de saúde", Ribas, Lutz, Vaz e Moreira foram novamente expostos aos mosquitos, sendo que Vaz foi picado mais uma vez em 22 de dezembro. Os resultados dessas sessōes de aplicação de mosquitos foram todos negativos.

Em 12 de janeiro de 1903 Vaz foi submetido à sua quarta aplicação de mosquitos, verificando-se então o primeiro resultado positivo. Entre 14 e 20 de janeiro Vaz desenvolveu sintomas típicos de uma "forma benigna da febre amarela" (calafrios, vômitos, fotofobia, dores generalizadas, raquialgia forte, febre, congestão cutânea da região toráxica), após o que se reestabeleceu (cf. DIRECTORIA..., 1936, p. 122, 130).

Em 20 de janeiro Lutz e Ribas aplicaram mosquitos infeccionados em mais dois voluntários, Januario Fiori e André Ramos (cf. DIRECTORIA..., 1936, p. 123, 124, 128).

Entre 23 e 27 de janeiro Ramos desenvolveu sintomas que indicavam "forma benigna da febre amarela" (febre, calafrios, dores na cabeça e no corpo, hiperemia das conjuntivas e do tórax, ânsias de vômito etc.) (cf. DIRECTORIA..., 1936, p. 124, 129).

Entre 23 e 29 de janeiro Fiori desenvolveu o completo "quadro mórbido da febre amarela" (febre, calafrios, dores na cabeça e no corpo, hiperemia das conjuntivas, da face e do tórax, raquialgia, estomatorragia gengival, inapetência, albuminúria, vômitos biliosos etc.) (cf. DIRECTORIA..., 1936, p. 123, 129).

Decorrido o período de evolução da moléstia, Ramos e Fiori entraram em convalescença e se reestabeleceram.

A "2. a série de experiências" sobre a transmissão da febre amarela pelo mosquito Stegomyia fasciata foi realizada entre 20 de abril e $10^{\circ}$ de maio de 1903. Durante esse período, Ribas e Lutz conduziram experimento em que três homens (Malagutti Giuseppi, Angelo Paroletti e Siniscalchi Giovanni) usaram durante várias noites seguidas vestimentas e roupas de cama sujas de sangue, vômito e fezes de amarelentos, sendo que nenhum deles adoeceu. $\mathrm{O}$ recinto em que os voluntários ficaram confinados foi mantido em condiçôes ambientais supostamente favoráveis à gestação de "miasmas" (temperatura entre 20 e $25^{\circ}$, proteção contra a insolação direta). Malagutti iniciou sua participação em 20/4, Angelo Paroletti em 21/4 e Siniscalchi Giovanni em 23/4. Os resultados do experimento sugeriam que "é completamente infundada a crença na transmissão da febre amarela pelos fomites” (DIRECTORIA..., 1936, p. 133-4).

Entre 30 de abril e 10 de maio de 1903 os voluntários participantes dessa "2. a série de experiências" permaneceram em observação no Hospital de Isolamento, a fim de que não se alegasse que não havia decorrido tempo suficiente para a manifestação da doença (cf. DIRECTORIA..., 1936, p. 139-40).

Nos relatórios que apresentou à Diretoria do Serviço Sanitário do Estado de São Paulo, a comissão médica que acompanhou as experiências realizadas no Hospital de Isolamento concluiu que "a transmissibilidade da febre amarela pelos mosquitos é um fato positivo adquirido 
Pesquisas sobre a febre amarela...

para a ciência" e que somente agindo "direta e indiretamente contra o Stegomyia fasciata" é que se conseguirá "lavar do corpo do Estado de São Paulo a negra mácula que o desfigura e desonra, ameaçando sustar a sua evolução econômica” (DIRECTORIA..., 1936, p. 124, 136).

Note-se que aproximadamente na mesma época a missão francesa para o estudo da febre amarela no Rio de Janeiro, composta por Marchoux, Salimbeni e Simond, também confirma a teoria do mosquito e as pesquisas da Comissão Reed em Havana (PESSÔA \& MARTINS, 1974, p. 874; BIER, 1949, p. 597, 599).

Apesar de terem sido conduzidas com todo o rigor possível, as experiências do Hospital de Isolamento não conseguiram contentar a todos. Para dr. Arthur Mendonça, tradicional adversário da teoria do mosquito, os indivíduos que participaram dos experimentos de inoculação não haviam desenvolvido febre amarela verdadeira, mas somente um estado mórbido corriqueiro "que o povo chama de sapeca e que os médicos chamam de febre efêmera", não havendo portanto evidência concreta de que os mosquitos poderiam constituir agentes transmissores da febre amarela (cf. MENDONÇA, 1903, p. 55).

De fato, no Brasil, não foram experiências como as do Hospital de Isolamento que convenceram os homens da ciência quanto à validade da teoria do mosquito. Não. Esse feito deve ser creditado principalmente à campanha contra a febre amarela liderada por Oswaldo Cruz no Rio de Janeiro (1903-1906). Durante essa campanha, apesar da forte oposição de diversos setores da sociedade (imprensa, poder legislativo, classe médica...) e da população em geral, ficou evidente que as medidas de combate ao mosquito adotadas pelo governo federal realmente conseguiram fazer com que a incidência da febre amarela declinasse.

Em 1903 Oswaldo Cruz assumiu o cargo de diretor geral de Saúde Pública e formou uma brigada de "85 homens" para o combate à febre amarela, a qual foi posteriormente ampliada para 300 homens. Esses "mata-mosquitos" ficaram incumbidos de

\begin{abstract}
percorrer quintais e jardins, subir ao telhado das casas, a fim de remover tudo quanto pudesse favorecer formação de depósitos d"água. Cumpria-lhes [...] retirar detritos, lixo dos quintais, depósitos de poeira que o tempo acumula nos telhados e nas calhas, impedindo o escoamento das águas pluviais [...]; incumbia-lhes nivelar as depressöes do solo, petrolizar lagos, isto é, lançar neles pequena porçāo de petróleo que forma, na superficie, delgadissima camada, suficiente, porém, para asfixiar as larvas; ou recomendar a criação de peixes, os quais devoram as larvas; selar caixas d'água para impedir a penetração de mosquitos etc.
\end{abstract}

Os mata-mosquitos deveriam realizar também "o expurgo das casas (desinfecções, fumigações de enxofre e piretro), a vigilância, a remoção dos doentes para o Hospital de Isolamento". A todas essas medidas viria a somar-se uma outra ainda mais drástica: a "demolição de casebres insaneáveis, onde se abrigavam e se multiplicavam mosquitos e ratos" (cf. SALLES GUERRA, 1940, p. 73, 75-6). Foram determinadas visitas domiciliares, fumigaçôes, petrolizações, isolamento de doentes, intimações de reformas, interdições e demoliçôes. O solo sob as habitações era "impermeabilizado". As residências em cujo interior existiam cômodos abafados foram dotadas de "grandes aberturas e janelas", a fim de "permitir a livre circulação do ar e da luz" (BOTELHO, 1917, p. 614; cf. BENCHIMOL, 1990, p. 24-5).

Essas medidas, embora altamente impopulares, surtiram notável efeito no sentido de controlar as epidemias. Assim, a partir de 1906, uma grande euforia foi-se "apoderando da opinião pública” (cf. BENCHIMOL \& TEIXEIRA, 1993, p. 25), e a imprensa, os médicos, os políticos e os homens da ciência subitamente mudaram seu discurso, deixando de contestar a teoria do mosquito. E Oswaldo Cruz, que fora de uma hora para outra elevado à categoria de herói nacional, pôde finalmente fazer a vitoriosa comunicação de que a febre amarela não mais existia "sob a forma epidêmica no Rio" (SALLES GUERRA, 1940, p. 78; cf. STEPAN, 1976, p. 90). 
Nessa ocasião, portanto, são os argumentos empíricos que convencem os cientistas quanto à validade de uma determinada hipótese (teoria do mosquito) e não os argumentos científicos produzidos por pesquisadores profissionais (Reed, Carrol e Agramonte, Lutz e Ribas, comissão francesa etc.).

\section{Considerações finais}

Por meio dos relatos e análises aqui apresentados, procuramos mostrar que a história das pesquisas sobre a febre amarela (1881-1903) fornece um interessante material para exemplificar os seguintes aspectos da atividade científica, entre outros:

(a) A influência que os contextos econômico, social e político exercem sobre a pesquisa científica. Os esforços massivos voltados para a investigação de doenças tropicais como a febre amarela só se tornaram possíveis em razão de interesses econômicos e políticos, e não em razão de preocupações humanitárias. Além disso, tais esforços foram desenvolvidos apenas até o ponto em que foi possível garantir o patamar mínimo essencial para a continuidade da expansão capitalista nos países da América Latina e África.

(b) $\mathrm{O}$ caráter coletivo, controvertido e não-linear do processo de produção de conhecimentos na ciência. Inúmeros cientistas em diversos países do mundo estiveram envolvidos nas pesquisas e debates sobre a febre amarela, não sendo possível eleger alguns poucos cientistas "geniais" que formularam e resolveram sozinhos os diversos problemas científicos que se mostraram relevantes.

(c) A natureza arbitrária dos conhecimentos científicos, no sentido de que representam "formas de ver", disso resultando que não são perenes, e que sua discussão não se dá sob um clima que prime apenas pela razão. As hipóteses científicas sobre a febre amarela surgiram e foram defendidas ou rejeitadas sob a influência de diversas perspectivas parciais sustentadas por diversos grupos e instituições em conflito. Além disso, uma das hipóteses que se mostrou mais frutífera, isto é, a teoria do mosquito, estava justamente entre aquelas que, no período entre 1880 e 1900, pareciam mais absurdas ou sem sentido.

(d) O papel pouco cabal desempenhado pelas demonstrações experimentais, que, na verdade, não se mostram "irrefutáveis". Os trabalhos da Comissão Reed em Cuba e outras investigações de natureza experimental não foram suficientes para encerrar as acaloradas polêmicas que se desenrolavam no final do século XIX e início do século XX a respeito do modo de transmissão e do agente etiológico da febre amarela.

(e) O papel desempenhado pelos paradigmas, que conduzem não apenas a caminhos frutíferos, mas também a becos sem saída. A teoria microbiana das doenças, apesar de extremamente frutífera para a ciência médica, obstaculizou significativamente o estudo de doenças causadas por vírus ou carência nutricional, tais como a febre amarela, a varíola e o beribéri.

Esses exemplos nos parecem ricos e ilustrativos e, assim, esperamos que constituam subsídios úteis tanto aos pesquisadores da área de ensino de ciências como também aos profissionais que atuem como docentes e se interessem em estar inserindo conteúdos de História e Filosofia da Ciência em suas aulas. 
Pesquisas sobre a febre amarela...

\section{Referências}

ANTUNES, J. L. F. São Paulo: saúde e desenvolvimento (1870-1903): a instituição da rede estadual de saúde pública. In: ANTUNES, J. L. F., et al. (Org.). Instituto Adolfo Lutz: 100 anos do laboratório de saúde pública. São Paulo: Letras \& Letras, 1992. p. 15-41.

BASTOS, F. História da Ciência e Ensino de Biologia: a pesquisa médica sobre a febre amarela (18811903). São Paulo, 1998a. 212 p. Tese (Doutorado em Educação)-Faculdade de Educação da Universidade de São Paulo, São Paulo, 1998.

. O ensino de conteúdos de história e filosofia da ciência. Ciência \& Educação, Bauru, v. 5, n. 1 , p. 55-72, 1998 b.

BENCHIMOL, J. L. (Coord.). Manguinhos, do sonho à vida: a ciência na belle époque. Rio de Janeiro: Fundação Instituto Oswaldo Cruz, 1990. 248p.

.; TEIXEIRA, L. A. Cobras, lagartos \& outros bichos: uma história comparada dos institutos Oswaldo Cruz e Butantan. Rio de Janeiro: Editora da UFRJ, 1993. 225 p.

BIER, O. Bacteriologia e imunologia. 4. ed. São Paulo: Melhoramentos, 1949. 791p.

BOTELHO, J. O. Climate and hygiene fo Rio de Janeiro. In: PAN AMERICAN SCIENTIFIC CONGRESS, 2, 1915-1916, Washington. Proceedings... Washington: Gov. Print. Off., 1917. v. 1. p. 613-5.

BRAZIL, V. Emilio Ribas. Archivos de Hygiene e Saude Publica, São Paulo, v. 1, p. 7-12, 1936.

BREILH, J. Epidemiologia: economia, política e saúde. São Paulo: Hucitec, 1991. 276 p.

DIRECTORIA DO SERVIÇO SANITARIO DE SÃO PAULO. A febre amarella e o mosquito. Archivos de Hygiene e Saude Publica, São Paulo, v. 1, p. 119-42, 1936.

FERREIRA, R. F.; MARTINS, R. A. Os estudos de Pasteur sobre os bichos-da-seda e a gênese da teoria microbiana das doenças. Perspicillum, Rio de Janeiro, v. 9, n. 1, p. 113-175, 1995.

GALVÃO, P. A. A.; BOMFIM, P. C.; MA, C. A. P. Uma mensagem ao "Instituto Adolpho Lutz". In: ANTUNES, J. L. F.; NASCIMENTO, C. B.; NASSI, L. C.; PREGNOLATTO, N. p. (Org.). Instituto Adolfo Lutz: 100 anos do Laboratório de Saúde Pública. São Paulo: Letras \& Letras, 1992. p. 137-9.

GORGAS, W. C. Yellow fever and its erradication. In: PAN AMERICAN SCIENTIFIC CONGRESS, 2, 1915-1916, Washington. Proceedings... Washington: Gov. Print. Off., 1917. v. 1, p. 7-9.

HUBERMAN, L. História da riqueza do homem. 21. ed. Rio de Janeiro: Guanabara Koogan, 1986. 313 p.

LUTZ, A. Resposta. In: MENDONÇA, A. (Comp.). Febre amarella: a doutrina bacteriana de Sanarelli... São Paulo: Escola Typographica Salesiana, 1903. p. 16-20. 
- Reminiscencias da febre amarella no Estado de São Paulo. Memorias do Instituto Oswaldo Cruz, v. 24, n. 3, p. 127-42, 1930.

MENDONÇA, A. (Comp.). Febre amarella: a doutrina bacteriana de Sanarelli... São Paulo: Escola Typographica Salesiana, 1903. 136p.

NEIVA, A. A obra de Oswaldo Cruz e sua projeção na medicina brasileira. In: RIBEIRO, L. Medicina no Brasil. Rio de Janeiro: Imprensa Nacional, 1940. p. 59-66.

NOGUEIRA, P. The early history of yellow fever. In: SYMPOSIUM ON YELLOW FEVER, 1955, Philadelphia. Yellow fever: a symposium in commemoration of Carlos Juan Finlay. Philadelphia: Jefferson Medical College, 1955. p. 1-13.

O BRAZIL-MÉDICO. Rio de Janeiro: Faculdade de Medicina, 1887-1930. Semanal.

OSOL, A (Ed.). Dicionário médico Blakiston. 2. ed. São Paulo: Organização Andrei, 1987. 1169 p.

PESSÔA, S. B.; MARTINS, A.V. Parasitologia Médica. 9. ed. Rio de Janeiro: Guanabara Koogan, 1974. $1002 \mathrm{p}$.

REED, W.; CARROLL, J.; AGRAMONTE, A. The etiology of yellow fever. An additional note. Journal of the American Medical Association, Chicago, v. 36, n. 7, p. 431-40, feb. 1901.

RIBAS, E. A extincção da febre amarella no Estado de S. Paulo (Brasil) e na cidade do Rio de Janeiro. Revista Médica de São Paulo, São Paulo, v. 12, n. 10, p. 198-205, 1909.

. Nota sobre a extincção completa da febre amarella no estado de S. Paulo (Brasil). In: PAN AMERICAN SCIENTIFIC CONGRESS, 2, 1915-1916, Washington. Proceedings... Washington: Gov. Print. Off., 1917. v. 1, p. 123-6.

ROSEN, G. Uma história da saúde pública. São Paulo: Hucitec, 1994. 423 p.

SALLES GUERRA, E. Oswaldo Cruz: o saneador: o renovador da higiene e da medicina no Brasil. In: RIBEIRO, L. Medicina no Brasil. Rio de Janeiro: Imprensa Nacional, 1940. p. 66-94.

STEPAN, N. Gênese e evolução da ciência brasileira: Oswaldo Cruz e a política de investigação científica e médica. Rio de Janeiro: Artenova, 1976. 188 p.

STERNBERG, G. M. Report on the etiology and prevention of yellow fever. Washington: Government Printing Office, 1890. 271 p.

SYMPOSIUM ON YELLOW FEVER, 1955, Philadelphia. Yellow fever: a symposium in commemoration of Carlos Juan Finlay. Philadelphia: Jefferson Medical College, 1955. 101 p.

Agradecimentos:

Aos pareceristas de Ciência \& Educação, pelas críticas e sugestôes valiosas. 